\title{
Navigating between Disaggregating Nation States and Entrenching Processes of Globalisation Reconceptualising the Chinese Diaspora in Southeast Asia
}

Jacobsen, Michael

Document Version

Final published version

Publication date:

2007

License

CC BY-NC-ND

Citation for published version (APA):

Jacobsen, M. (2007). Navigating between Disaggregating Nation States and Entrenching Processes of Globalisation: Reconceptualising the Chinese Diaspora in Southeast Asia. Asia Research Centre. Copenhagen Business School. Copenhagen Discussion Papers No. 16

Link to publication in CBS Research Portal

General rights

Copyright and moral rights for the publications made accessible in the public portal are retained by the authors and/or other copyright owners and it is a condition of accessing publications that users recognise and abide by the legal requirements associated with these rights.

Take down policy

If you believe that this document breaches copyright please contact us (research.lib@cbs.dk) providing details, and we will remove access to the work immediately and investigate your claim.

Download date: 26. Apr. 2023 


\section{$16^{2007 \text { February }}$}

Navigating between Disaggregating Nation States and Entrenching Processes of Globalisation. Reconceptualising the Chinese Diaspora in Southeast Asia

Michael Jacobsen 
(c) Copyright is held by the author or authors of each Discussion Paper.

Copenhagen Discussion Papers cannot be republished, reprinted, or reproduced in any format without the permission of the paper's author or authors.

Note: The views expressed in each paper are those of the author or authors of the paper. They do not represent the views of the Asia Research Centre or Copenhagen Business School.

\section{Editor of the Copenhagen Discussion Papers:}

Associate Professor Michael Jacobsen

Email: mj.int@cbs.dk

\section{Asia Research Centre}

Copenhagen Business School

Porcelaenshaven 24

DK-2000 Frederiksberg

Denmark

Tel.: (+45) 38153396

Fax: (+45) 38152500

Email: cdp.int@cbs.dk

www.cbs.dk/arc 


\title{
Navigating between Disaggregating Nation States and Entrenching Processes of Globalisation. Reconceptualising the Chinese Diaspora in Southeast Asia
}

\author{
Michael Jacobsen \\ Associate Professor \\ Asia Research Centre \\ Copenhagen Business School \\ mj.int@cbs.dk
}

\begin{abstract}
This paper argues that the fluidity that permeates the contemporary international community is driven by especially political and economic globalisation, which has a huge impact of the relationship between the nation and the state. As the individual nation state is increasingly depending on the international community for its economic survival this dependency on the global has as a consequence that it rolls back aspects of national sovereignty thus opening up the national hinterland for further international influences. These developments initiate a process of disaggregating state and nation, meaning that a gradual disarticulation of the relationship between state and nation produces new societal spaces, which are contested by non-statist interest groups and transnational more or less deterritorialised ethnic affiliated groups and networks. The argument forwarded in this article is that the ethnic Chinese utilises these newly created spaces for setting up diasporic like networks thus providing substance for transnational ethnoscapes or nations without states.
\end{abstract}

Keywords: globalisation, nation state, diaspora, ethnicity, Chinese, Southeast Asia 


\section{Introduction}

When discussing the Chinese diaspora in especially a Southeast Asian context its coherent nature is often at the core of the discourse. According to several authors the Chinese diaspora is characterised by an enduring sense of transnational group identification and global linkages, which makes it well suited as an international channel for Chinese sojourners and migrants. The essence of these arrangements, generally based on narratives that pay tribute to the uniqueness of Chinese culture, is the so-called Guanxi networks, which characterises the different manifestations of this particular diaspora. It refers basically to national as well as transnational relationships revolving around language, ethnic, and kinship affiliations within and between Chinese communities thus giving them a comparative advantage over other networks because of their perceived common Confucian strength of mind. This is especially so when conducting intra-ethnic Chinese business in China and Southeast Asia, as these Guanxi networks have, according to proponents of this business approach, a capability of lowering transaction costs in these types of emerging markets where legal systems generally are underdeveloped.

This paper questions the coherence ascribed to the Chinese diaspora in a Southeast Asian context, and to the coherence of diasporic networks in general, arguing instead that a diaspora constitutes a decentred, multilevelled and fractious, generally ethnically affiliated, ideational network that allows people to move in and out of a given diaspora depending on their current social, economic and political situation. The adherence to a perceived affiliated diaspora thus depends on relative social, economic, and political contextual givens. An understanding of diaspora does therefore not depend on systemic network approaches, that is, theoretical constructs hovering above empirical and geographical constrains, but rather by analysing de facto socio-political contexts that delineate a given diaspora. 
By taking such an approach it is imperative to describe the actual social, political, and economic forces which have the capability of initiating changes in the overall societal embedment of the ethnic Chinese in Southeast Asia. This is done by analysing the interaction between the latter, his or her community of residence together with the individual Southeast Asian state's attitude towards the ethnic Chinese generally conceived of as a minority group within the national hinterland.

As the state does not exist in a vacuum but constitutes an integrated part of an international community then this relationship and the dynamics within it also has to be accounted for, as it colours the state's understanding of, in this particular case, the ethnic Chinese minority and its specific social, political, and perhaps more importantly, economic relationships, with its particular nation state of residence.

Basically, this paper argues that the fluidity that permeates the contemporary international community is driven by especially political and economic globalisation, which has a huge impact of the relationship between the nation and the state. As the individual nation state is increasingly depending on the international community for its economic survival this dependency on the global has as a consequence that it rolls back aspects of national sovereignty thus gradually opening up the national hinterland for further international influences. These developments initiate a process of disaggregating state and nation, meaning that a gradual disarticulation of the relationship between state and nation produces new societal spaces, which are contested by non-statist interest groups and transnational more or less deterritorialised ethnic affiliated groups and networks. The argument forwarded in this article is that the ethnic Chinese utilises these newly created spaces for setting up diasporic like networks thus providing substance for transnational ethnoscapes or nations without states, as these spaces are labelled by some authors. 
Such a reading of current affairs in an ever more globalising world leads towards a view that it is omnipotent and simultaneously local cum global in scope. The contemporary world can thus be characterised as displaying a high degree of time-space compression that allows us to immediately acknowledge different types of events regardless of where on earth they take place. It is this conception of immediacy that governs this author's perception of the essence of contemporary globalisation. This view will be employed during the following discussion of the relationship between a budding disaggregating of nation and state, changing perceptions of citizenship, and transnational migration framed in more or less diasporic networks. In relation to the latter an emphasis will put on the ethnic Chinese in especially Indonesia.

\section{On The Changing Mode of the Contemporary Nation State}

Just as perceptions of the extent of the world have changed down through history so have the conceptions and constitution of the (nation) state. Arguably, one has to distinguish between the main raison d'être for pre- and modern types of states. Whereas pre-modern states were mostly concerned with controlling trade routes and making political alliances with more or less collaborative cultures in a fluid and difficult to control surrounding political landscape, modern states, linking their legitimacy to managing a carefully carved out geographically area, are obsessed with policing national borders, maintaining state sovereignty, self-determination, and non-interference in an international community generally thought of as consisting of predatory fellow states.

The origin of the modern state is generally attributed to the Treaty of Westphalia on 24 October 1648 but it was only after the commencement of the industrial revolution in the beginning of the $18^{\text {th }}$ Century Europe that the state evolved into its present form, that is, towards a state with a closely defined national territory. Historically speaking, the notion and construction of 
the modern nation state is thus a relatively late comer. For example, the embryonic establishment of the Southeast Asia states only took off during the late colonial period and the contemporary Asian version of the modern nation state only began establishing itself during the transition from colonial to independent (nation) states in the mid $20^{\text {th }}$ Century. This type of state differs markedly from pre-colonial forms of 'states' in the region, as they were either based on collaboration between one or two sultanates or consisted of fragile alliances between a sultanate and tribal like chieftainships kept together by political and military relations baked by highly elaborated trade networks (on early state formation in Southeast Asia, see Reid 1993). The contemporary perception of antiquity and thus permanency attributed to the modern Asian nation state is thus based on atavistic inspired ideological references to such sultanates and chieftainships, thereby unwittingly underscoring their own truncated life span and political and ideological attempts to legitimate their current form and function.

The 'classical' conception of the contemporary nation state can in particular be allotted to the period after World War II, which entails, according to the realist school in international relation theory, a perception of the state as being an almost absolutist and total sovereign entity (see Krasner 1999). What is meant by that? Robert Jackson writes that the sovereignty that such a state ascribes to is to be perceived as a legal, absolute, and unitary condition. It is legal in that a sovereign state is not subordinate to another sovereign but is necessarily equal to it by international law - although not necessarily by international fact. It is absolute in that sovereignty is either present or absent. When a country is sovereign it is independent categorically: there is no intermediate condition. It is unitary in that a sovereign state is a supreme authority within its own jurisdiction. This is the case whether or not a state has a unitary or a federal constitution, because in either case it is a sole authority in its external relations with other states (Jackson 1990: 32). According to this the state is thus the sole and ultimate organiser of the national community. 
A much used way of further knitting the relationship between nation and state together is to construct a nationalist inspired societal membrane between nations thus creating the necessary 'other' in terms of national selfidentification. This is done, for example, by imposing specific notions of citizenship that automatically exclude anyone who do not fall into such statist defined categories. David Castles and Alastair Davidson emphasis three main types of citizenship:

ius sanguinis: citizenship is based on ethnicity or an ideologically constructed folk model which operates on the notion of descent from a national from within the country concerned when electability for citizenship is determined.

ius soli: citizenship is based on multiple ethnic groups where birth in the territory of the country in question is more important than descent from citizens within a national legitimate ethnic group.

ius domicile: this is a rather new way of gaining entitlement to citizenship as it is possible to achieve through mere residence in the national territory. It has also been referred to as a law of residence by some analysts.

According to the authors the colonial powers usually introduced the nationality rules that existed for their own subjects in their colonies. This meant that throughout the British and American empires ius soli became law, while in French and Dutch possessions a combination between ius soli and a modified ius sanguinis was typically established (Castles and Davidson 2000: 190).

All three main types of achieving citizenship refer to different categories of societies even though they are all based on the above defined classical notion of the nation state. Citizenship defined along ius sanguinis lines makes it extremely difficult for non-nationals to achieve citizenship if they do not have a relative in the pertinent nation. And in case they do but these relatives are not born in the nation then it is still difficult to achieve citizenship. In this case it is completely up to the discretion of the individual state to grant a non-native 
citizenship, which gives the state a high degree of control over who are to become citizens and not. All ethnic groups which have been incorporated into these states after independence thus faces immense obstacles in terms of jobs, education, health care systems, political rights, etc., as they are not regarded as original to the nation and thus not automatically entitled to become citizens. As a generic definition states which base themselves on this kind of citizenship can be termed ethnocratic states, as they base themselves on one or a small core of dominating (ethnic) group(s). According to Sautman (2002: 3) an ethnocracy is:

... a descriptor for a regime that expresses the identity and aspirations of one ethnic group in an ethnically divided society, based on rule over other ethnic groups who are accorded only qualified rights to citizenship. Ethnocracy's reason d'etre is to secure the key instruments of state power for the dominant ethnic collectivity; it allows only those facets of democracy consistent with the demos being identical with that groups and not the collective population.

According to Castles and Davidson of countries which are based on principles close to those of ius sanguinis and ethnocracies one finds Papua New Guinea, Fiji, Indonesia, Malaysia, Burma, Vietnam, South Korea, Taiwan, Japan, and China.

In relation to countries which have adopted the ius soli principle it is much easier to obtain citizenship. Castles and Davidson note that all nations which fall into this category are multiethnic with both indigenous minorities and a large population of foreign labours. Such states may be regarded as highly progressive because of the porousness of their citizenship rules which make them clearly distinguishable from the former colonies, which have reversed the British and American ius soli rules in favour of ius sanguinis ones. Of countries in the ius soli category we find Australia, New Zealand, India, Singapore, and the Philippines (Castles and Davidson 2000: 190-91). 
Finally, ius domicile is generally combined with one of the two other main categories of citizenship. Paradoxically, according to Castles and Davidson it is countries that base their rules of citizenship on ius sanguinis that experiments most with ius domicile rules as a supplement to the general rules. The main idea behind this is to provide young people of immigrant origin with an option for becoming citizens. This development has a footing in a cynical calculation that the exclusion from citizenship is problematic, leading to social marginalisation, political exclusion, conflict, and racism. This experiment is thus born out of a need to preserve social and political stability (Castles and Davidson 2000: 93-94).

Most if not all nations in the Asia-Pacific region is thus based more or less exclusively on either ius sanguinis or ius soli principles, as they provide the state with strong tools for controlling the flow of people in and out of its nation. It is only in regional organisations such as the EU that serious experiments with ius domicile has taken place. The reason d'être for this is likewise cynical as the increasing incorporation of nation states into a more integrated union has made this development imperative. This has meant a gradually easing of restriction of citizenship amongst EU citizens so as to further a higher degree of labour mobility and migration within the union, a mobility that is essential as the individual states develop in different tempi. How this, however, is going to be managed after the inclusion of 12 eastern and central European countries in 2004 and 2007 respectively has yet to be seen.

As the Asia-Pacific region does not yet have this kind of political and economic integrated regions the imperative for incorporating ius domicile principles in their notions of citizenship has not arisen. The current development of regionalism is generally a statist driven process that has so far resulted in the formation of, for example, AFTA, APEC, ASEAN+1 and $A S E A N+3$, all based on principles of non-intervention in the internal affairs of the individual member states. This non-intervention principle fits especially 
well the ASEAN countries, as it reinforces their efforts of jealously safeguarding their relatively newly won sovereignty. I return to this in a later section when discussing the difference between regionalism and regionalisation and what this means for questions concerning citizenship and national coherence in terms of a budding disaggregation of nation and state.

\section{On Expanding Globalisation and Contracting Nation States}

The question now is whether the above described close relationship between concepts of citizenship, sovereignty, state, nation, and principles of regionalism are still possible in an international community that has become much more complex, interconnected and volatile during the last three decades. The reason for this scepticism is that various processes of globalisation, especially those which have to do with the increasing transnational mobility of finance capital, telecommunication technology, and transportation, have gradually become more entrenched nationally thereby strengthening the internationally oriented network already established there.

Elaborating on the economic aspect of globalisation, Holm and Sørensen (1995) advance a scenario in which distinct national economies are subsumed and re-articulated into the global finance system by essentially international processes and transactions. Domestic politics, whether those of the private corporations or the public regulators, now have routinely to take into account the international flow of capital in their sphere of operations. The national is thus permeated and transformed by the international. Holm and Sørensen furthermore maintain that true economic globalisation invokes a qualitatively shift towards a global economic system that is no longer based on autonomous national economies but on a consolidated global marketplace for production, distribution, and consumption. According to this perspective, the global economy dominates the national economies existing within it (Holm and Sørensen 1995: 5). 
This portrays an international community in which nation states are no longer capable of controlling the internal flow of capital due to the current transnational organisation of those flows. The scenario presented by the neorealists towards contemporary processes of globalisation does not, it seems, explain the dynamics behind the rapid changing international environment. Nation states are gradually becoming disempowered when implementing rules and regulations for managing economic transactions. The international community represented by WTO, are, for instance, forcing states to abide toward international standards when working out domestic economic policies. Furthermore, the previously fixed nature of centres of capital control has been transformed into multiple and shifting centres of capital accumulation. The East and Southeast Asian tiger and dragon economies as centres of capital accumulation before the economic crisis hit them in July 1997, together with the current rising economic might of Mainland China and India, stand in strong contrast to the continuing problems the traditional centres of capital accumulation, the US and Europe, are currently facing. The contemporary era of globalisation is thus characterised by shifting capital centres, as the global economy has become highly mobile and more or less immune to statist regulations and national borders.

The contemporary nation states have thus seen their room for manoeuvring confined by this new economic order. This has entailed a hollowing out of their sovereignty as the IMF, ADB, the World Bank, WTO, ILO, and the UN have demanded acceding to and incorporation of international political and economic conventions and regulations when designing national political and economic policies. In case a state violates the agreed to international conventions and regulations sanctions are being imposed on it so as to force it to comply. The main purpose of these sanctions is to reintegrate the erratic state into the international community, as it despite the breaches still constitutes an integrated part of that community. Arguably, there are no room for non-complying nation states outside the international community as the latter encompasses the whole globe. As mentioned in the 
beginning of this paper, today there is only one perception of the world even though it might be sub-divided or structured in many different ways. This is contrary to previous perceptions in which several conceptions of the world competed with each other for constituting the true one; perceptions which now must be considered archaic and if applied today an anachronism.

Paradoxically, these international political initiatives, reinforced by economic globalisation, also empowered various ethnic groups within the national hinterlands thereby enabling them to mount pressure on the state to grant them recognition, from political autonomy to cultural respect. For example, a budding supranational morality framed in universal human rights agendas has created space for ethnic groups to promote issues on an international level, which again have the capability of initiating qualitatively shifts in the conditions of people's lives at the local level (Holm and Sørensen 1995: 5, Castles and Davidson 2000: 204). ${ }^{1}$ The same is true for a wide range of NGOs.

Rephrased, it is possible to argue that various aspect of globalisation are leading towards an assertive resurgence of local identities thereby producing an increasing social and political awareness within ethnic groups thus making them influential players in the national political power game. Furthermore, globalisation is encouraging this development by supporting the emergence of a budding supranational moral construct based on an adherence to a universal human rights regime together with the implementation of notions of good governance and transparent democracy. Admittedly, this seems highly hypothetical when current international affairs, governed as they are by predatory neo-liberal strategies and total American political, economic and military hegemony, dictate a partial return to earlier anarchic periods in the international community. How the international community will deal with this negative development is still to be seen. Perhaps the solution to this problem is not to be sought in the political realm but rather 
in the economic imperatives that the global economy is enforcing on the individual nation states.

Put together, the dual effects of globalisation, that is, international intervention and local empowerment within the national sphere, constitute the beginning and end in an interrelated movement. This is what Friedman (1998: 6) has coined the packing in of global events, products and frameworks into the local, not so as to de-localise the local, but rather change its content, not least in terms of identity. An interesting consequence of the connection between local identities and international normative patterns of behaviour is that they tend to reinforce each other. As we have seen it several times in Indonesia, the state cannot legitimately force ethnic groups into submission by referring the matter to a question of national security without immediately having the international community on its back. The reason is that having an ethnic identity besides a national one is legitimate in the eyes of the international community, spelled out as it is in the International Convention on the Elimination of All Forms of Discriminination that Indonesia ratified on 25 September 1999 (Chin 2000: 30-31). As an humanitarian approach now forms part of the International Monetary Fund's humanitarian platform and the latter constitutes one of main designers of Indonesia's structural adjustment programme the Indonesian national government is forced to initiate policies in the form of, for example, economic decentralisation and regional autonomy so as to guarantee the rights of ethnic groups to participate in the current transformation of the Indonesian state and nation. This goes in relation to the organisational, political, ideological and economical aspects of nation making. Ethnic groups are thus secured, at least theoretically, international support in their jockeying for cultural recognition and political influence. ${ }^{2}$

The international community is gradually becoming more globally encompassing and more deeply entrenched within the individual nation state. This enlargement of the international space at the expense of the individual nation state has created new transnational spaces that are heavily contested 
by various sub-national groups, which utilises them for transnational networking thus providing substance to what Ohmae (1995) and Guibernau (1996) tentatively has defined nations without states. Before I turn towards those kinds of 'in between' spaces or new frameworks for processes of nonstatist regionalisation it is important to address the question of the composition of the state cum nation in a global era.

\section{Towards a Disaggregation of Nation and State?}

Taking the volatile developments within the international community into account one is almost forced to ask whether the classical form of the state has reached its climax, historically speaking? For David Jacobson (1998) new transnational, international and regional entities, from international human rights institutions to the European Union are all constraining the state in some respects, and enhancing its role in others. He continues that today we are witnessing a gradual disaggregation of the nation state. The political, communal, and territorial components of the nation state, once thought to be deeply entangled, are gradually being unbundled. Territory no longer constitutes identity in that a territory and a people are no longer viewed as being inextricably linked. Diasporas and transnational identities are increasingly common. Jacobson stresses, however, that the state is not in a decline; on the contrary, its bureaucratic role is enhanced. It is the marriage between state and nation that is in question (Jacobson 1998: 444).

In order to assess this statement a point of departure can be taken in one of the defining characteristics of the classical concept of the nation state, namely citizenship. As discussed previously this was and still is mainly coined in terms of either ius sanguinis or ius soli. Despite the difference between the two concepts in obtaining citizenship they both refer to individuals who belong to a coherent entity made up of a functional relationship between state and nation. 
One of the main characteristics of the present era besides those described above is a high degree of labour mobility and migration of various kinds. These movements are closely related to economic globalisation that enforces a complex region wide distribution of production modes and sites according to where it is most profitable. This encourages to even higher levels of transnational labour migration as labour conditions wax and wane according to changing economic tides globally as well as within the individual nation state. This mobility of people between nations and regions exert a major pressure on the concept of citizenship to cope with the flow of noncitizens in and out of the respective national borders.

Most of these migrants do not stand a change of becoming citizens in their current country of residence, as they do not live up the pre-set definitions of either ius sanguinis or ius soli. Instead they are generally being categorised as either denizens (foreigners with permanent residence) or margizens (contract workers or undocumented workers). As such they are maginalised by their community of residence in terms of political influence and access to economic and social benefits.

According to the discussion on the relationship between the international community and the nation state the notion of promoting singular nationalities in a globalising world does not make sense in contemporary processes of regionalisation. This fact, however, does not seem to seep into the diplomatic discourse on statist initiated regional cooperation. For example, during a seminar series on the relationship between Mainland China and ASEAN at Hong Kong University in January 2003, in which diplomats from especially Mainland China presented their view on East and Southeast Asian regionalism, it was time and again emphasised that the main building blocks for regional cooperation were first and foremost mutual respect for national sovereignty, non-interference in national affairs, and regional cooperation based on consensus thus leaving binding treaties out of the question. In relation to regional cooperation per se the diplomats emphasised that even 
though it was framed within a multinational forum the ultimate relationship between the member states was based on non-binding bilateral agreements. So much for mutual trust within the East and Southeast Asian region and among the nation states herein! The so-called 'ASEAN Free Trade Area', which is to eliminate import tariffs in 2015 at the latest, is in for a difficult period, as it entails a softening stand on current perceptions of national sovereignty.

This official view of regional cooperation within East and Southeast Asia clashes head on with an analytical approach towards the relationship between the international community and nation states as discussed above. What we are confronted with here is an almost Thomas Hobbesian inspired anarchic perception of the relationship between sovereign states. Perhaps this perception guided the nature of the speakers at the seminar; they were, as mentioned, all diplomats with certain responsibilities towards their respective states.

Nonetheless, the conventional notion of citizenship, ius sanguinis and ius soli, together with classifications of migrants of various sorts as either denizens or margizens are increasingly being attacked by a transforming international community which is forcing the individual nation state to reorganise its basic setup. This goes especially for those nation states which base their perception of citizenship on principles of ius sanguinis, and that is most of the countries in the Asia-Pacific region. As globalisation is increasingly encroaching on the sovereign aspect of nationhood thereby facilitating a growing flow of migrant workers in and out of the individual nation state, then paradoxically these migrants are increasingly confronting problems when settling down in their host communities, as the latter desperately tries to impose new rules to regulate the influx of labour thus attempting to block the holes in the national borders. The main question to be addressed in this connection is, however, for how long the conventional statist perception of sovereignty and citizenship within a coherent national framework can hold 
against the changing tides within the international community of which they are an unbreakable part (Ong 1999).

The contradiction between political rhetoric as forwarded by the diplomats concerning the importance of upholding national coherence in relation to statist initiated regionalisation programmes and actual political and economic societal transformations within, for example, Southeast Asia are gradually becoming increasingly exposed. This is because statist induced regionalism in the form of politically, economical, and military cooperation clashes with a deepening transnational fluidity of the social, cultural and political landscape across the region thus exhibiting a progressing disaggregation between the individual state and its respective national hinterland.

\section{Reassessing the Ethnic Chinese Diaspora Against The Backdrop Of Entrenching Processes Of Globalisation}

The all important point of intersection in this discourse is the relationship between the concepts of regionalism and regionalisation, as the two refer to different societal processes. Regionalism refers to the operation of formal institutions (e.g. APEC and ASEAN); that is, state-led processes concerned with re-organising regional space along certain national political lines. In contrast, regionalisation refers to a bottom-up process of regional integration, for example, ASEAN+3, involving not only broad-based state and intergovernmental institutions, but also strategic interactions and choices of a whole range of non-state actors', for example, ethnic groups, business networks, and non-governmental organisations. Only little has been written on regionalisation, implying a lack of knowledge about processes of regionalisation that occur on the ground, independently of state-led spatial reorganisation. This returns us to the previous discussion on the production of space, that is, processes in which the international community is gradually becoming more globally encompassing and deeper entrenched within the 
individual nation state. This enlargement of the international room creates new transnational spaces at the expense of the nation states that are heavily contested by various sub-national groups which utilises them for transnational networking thus providing substance for de facto processes of non-statist regionalisation.

The process of transgressing nationally defined spaces involves the emergence of new forms of local and transnational spatial organisations such as supranational NGOs, transnational business communities, and crossborder diasporic communities based on more or less deterritorialised (ethnic) identities. Arguably, processes of globalisation is thus implicated in the construction of supra- and sub-national spaces thereby disrupting old forms of spatial organisations as defined by the state while at the same time producing new and alternative non-statist spaces of power thus further threatening state sovereignty by reducing the room it is supposed to cover (Sassen 2000).

This prompts us to forward the proposition that in modern global capitalism, there are no simplistic distinctions between the economic, the political or the cultural. Rather, these elements are all intertwined with the process of capital accumulation. Arguably, the production of identity is implicated with the production of economic and social power. In this context, identity becomes a form of ethnic capital disseminated through the creation of new spatial zones in the form of, for example, transnational business communities and ethnic affiliated diasporas or 'ethnoscapes' to employ a term coined by Appadurai (1991). Important related themes to be incorporated when studying such new spatial configurations include a disentanglement of the relationship between sovereignty, citizenship, national borders within a nation-state matrix, as well as the growing internationalisation of ethnic identities, together with a rise of multiple citizenship, seen as a natural outcome of an increasing disaggregation between state and nation (Jacobson 1998). 
Paying special attention to the ethnic Chinese diaspora in Southeast Asia and how they engage in the production of new cross-border spaces, Ong (1999) has defined ethnicity as a sorting mechanism for the creation of new spatial entities. According to this, the fragmentation of different spatial zones enables ethnicity to become an important key mechanism in determining the boundaries of these new spaces of power. Generally, these new entities are assigned to transnational ethnoscapes but they can also be described as new societal constellations, which are domestically configured along ethnic lines. I have described these developments in my earlier work on political fault-lines in North Sulawesi in Eastern Indonesia, where such new spaces of power manifest themselves in political mobilisation and stratification of different ethno-cultural groups thus underlining an uneven diffusion of power within a nation-state, that power is not just a top-down state governed phenomenon but is manifest at all societal levels, and that constellations of power are reflections of social and political tensions or developments fostered by domestically as well as international factors (Jacobsen 2002a).

Returning to a transnational sphere I would argue by employing a fragmented and multi-layered conception of diasporic spaces, as migrants flow in and out of their respective diaspora through processes of 'diasporasation' and 'de-diasporasation'; that is, diasporic movements which are determined by individual social strategies together with localised political and economic constrains (Riggs 2001), this would open up a whole new array of questions concerning the production of new spaces identified as either inter-ethnic or inter-diasporic relations within and between nation states.

For example, Gomez and Hsiao (2001) write that individual ethnic Chinese entrepreneurs do not necessarily make business deals with each other on the basis of guanxi practices; that is, through ethnically defined transnational networks which facilitate business deals among Chinese entrepreneurs (Luo 2000), but with whoever can provide them with a profit, be it with intra-ethnic or inter-ethnic business 'others', thus linking up with 
pertinent non-Chinese business communities within or outside their country of residence. Furthermore, Gomez and Hsiao are critical of the literature that highlights the importance of cultural infused dynamics of the ethnic Chinese entrepreneurs. They contest the thesis that the institutions, norms and practices of ethnic Chinese are the main reason for the growth of their enterprises. Finally, they question whether Chinese entrepreneurs have depended primarily on business networks based on shared identities to develop their corporate base. They thus distance themselves from the massive literature on Guanxi relationships and their influence on Chinese business practices (for an overview, see Li and Wright 1999)

Guanxi networks are thus not essential for doing business between ethnic Chinese entrepreneurs, as argued by Luo (2000) and Yang (1994), Weidenbaum and Hughes (1996), and Kotkin (1992), thereby questioning the coherent nature of these networks. Arguably, Guanxi business networks are thus but one strategy among other business strategies employed, when engaging ethnic- and non-ethnic Chinese business enterprises in creating new national and international spaces of transactions thus confirming Riggs' notion of diasporasation and de-diasporasation. Furthermore, this hypothesis reflects Dirlik's (1996) proposition that Guanxi business practices is an ethnicisation of capitalist practice, not a specific Chinese economy paralleling global capitalism.

The all-encompassing and coherent nature generally attributed to Guanxi networks is also prevalent in discourses on the Chinese diaspora, conceived of as constituting an international router in relation to ethnic Chinese (business) networks (McKeown 2001, Bolt 2000). For example, for Kotkin (1992) the Chinese diaspora is characterised by an enduring sense of group identification and global linkages, and for Callahan (2002) the comparative advantage of the diaspora's Confucian capitalism is that cultural ties lower the transaction costs of doing business in China and Southeast Asia, where legal systems are underdeveloped. This conception of diasporic 
coherence is also prominent in the more theoretical literature on diaspora (Brah 1996, Safran 1999, Clifford 1994). For example, Shuval (2000), echoing Cohen (1997), finds that diaspora is a social construct founded on narratives, mythology, history, and virtual elements, all of which play a vital role in establishing a diasporic narrative.

When taking a critical look at the literature on Chinese business enterprises and guanxi network in East and Southeast Asia, however, it becomes clear that such networks are multi-dimensional in terms of both meaning and function. For example, Yao Souchou writes that in China the term guanxi refers to any form of relatedness. It does not have any connotations specifically related to either commercial or political activities. In fact, guanxi is a generic term on which phrases representing more specific forms of relatedness are built. Thus, according to Yao we have guoji guanxi or international relations, routi guanxi or carnal relationships, fuji guanxi or marital relationships and so on. All these kinds of guanxi vary in terms of their respective emotional depth, social context and ethical bond. The social connectedness in the commercial world thus represents but one type of guanxi among many, so therefore we should strictly refer to shangye guanxi or commercial guanxi, when talking about guanxi practices in a business context (Yao 2002 2002: 236).

Zooming further in on the relationship between guanxi and business, Wong (1998), Gomez and Hsiao (2001) and Jacobsen (2004) have problems finding evidence of that dyadic-linked guanxi affiliated business deals in either a local, national or transnational context dominate the business field. On the contrary, we find that ethnic Chinese transnational business relations are generally based on ad hoc arrangements and at best truncated forms of networking practices (Gomez 2004). By this is meant when Southeast Asian Chinese entrepreneurs, especially those representing small and medium sized enterprises, decide to transnationalise their business they might initially connect to fellow Chinese entrepreneurs, either through family connections or 
previously utilised business connections. After this initial contact they branch out to the non-Chinese local business community in order to 'sink in' and tap on to the local business opportunities. This is what is meant by truncated business networks. The latter are thus shallow in terms of time and not necessarily confined to intra-ethnic relations but just as well to inter-ethnic business relations. Cribb (2000) furthermore contest the hypothesis that the various institutions, norms and practices of ethnic Chinese are the growth engine behind their enterprises. ${ }^{3}$ On the contrary, profit motives combined with a pragmatic reading of a given societal landscape in which to operate seem to prevail when doing business - be it with intra- or inter-ethnic partners.

Echoing the above argument that ethnic Chinese networks and diaspora are not necessarily coherent constructs len Ang (2001) furthermore sounds a warning note saying that one has to recognise the doubleedgedness of diasporic identity, the latter being the main signifier of the concept that might otherwise not refer to anything else! She writes:

Thus, while the transnationalism of diasporas is often taken as an implicit point of critique of the territorial boundedness and the internally homogenising perspective of the nation state, the limits of diaspora lie precisely in its own assumed boundedness, its inevitable tendency to stress its internal coherence and unity, logically set apart from 'others'. Ultimately, diaspora is a concept of sameness-in-dispersal, not of togetherness-indifference (Ang 2001: 12-13).

Playing on the definition of diaspora as literally meaning 'the scattering of seeds' Ang thus defines diasporic networks as producing subjects for whom notions of identity and belonging are unsettled. According to her, diasporic subjects are exemplary cases of the multiple and hybrid subjectivities favoured by post-modern and post-structuralist theory. A dominant tendency, Ang continues, in thinking about the Chinese diaspora is 
to suppress the ways in which diasporic identities are produced through creolisation and hybridisation in favour of a hierarchical centring and a linear rerouting back to imagined ancestral home. She cites Clifford in this connection:

The centring of diasporas around an axis of origin and return overrides the specific local interactions (identifications and ruptures, both constructive and defensive) necessary for the maintenance of diasporic social forms. The empowering paradox of diaspora is that dwelling here assumes solidarity and connection there. But there is not necessarily a single place or an exclusivist nation (Clifford 1997: 269, italics in original, cited in Ang 2001).

Ang argues that for Clifford, and perhaps for herself, the most important aspect of diasporic formations is the multiplicity of 'here's and there's' which together make up 'decentred, partially overlapping networks of communication, travel, trade, and kinship that connect the different communities of a transnational "people".' (Ang 2001: 44-45).

Such a decentred conception of diaspora in which the constitution of identity is based on creolisation or hybridisation if you like, positions cultural interaction and identification in the field of social expediency and political strategy. Playing on the interaction between achieved and ascribed identity and adding a time perspective of about one generation for allowing you to internalise the various practises of your community of residence, it is tempting to say that you are what you are expected to be; a context determined individual positioning that reflects your relationship towards your current country of residence. Consequently, having an identity as an ethnic Chinese in, for example, Malaysia or Indonesia does not necessarily imply that you are affiliated to Mainland China or devoted to Chinese culture and identity. On the contrary, you are a Malaysian or Indonesian of ethnic Chinese descent who for the time being has deposited your social and political loyalty in the local powers that be. ${ }^{4}$ 
The political potency of ethnic identities is not lost on state ideologues who often try to rein in a plurality of ethnic identities in terms of multicultural ideologies. Ang defines the latter as a government policy to manage cultural diversity within a pluralist nation state. If the nation state can no longer maintain its homogeneity, based of the concept of ius sanguinis, then the second best solution would be to allow for the preservation of a diversity of cultures, but within certain, well-defined limits, for example based on ius soli principles of citizenship, so as not to disturb or threaten national unity. In short, according to Ang, multiculturalism is based on the fantasy that the social challenge of togetherness-in-difference can be addressed by reducing it to an image of living-apart-together. Basically, multiculturalism is nothing more but a more complex form of nationalism, aimed at securing national boundaries in an increasingly borderless world (Ang 2001: 14, 16)

In writing about multiculturalism she notes that identity politics is a logical offshoot of the decline of assimilationism and its illusory promise of equality of the basis of a strived-for but never achieved sameness. The politics of identity relies quintessentially on the recognition and mobilisation of differences once the ideal of sameness has proved unreachably. Claiming one's difference from the mainstream of dominant national culture and turning it into symbolic capital has become a powerful and attractive strategy among those who have never quite belonged, or have been made to feel that they do not quite belong in the West or any other places for that matter. The preferred name for that symbolic capital is 'diaspora' (Ang 2001: 11-12).

\section{A Case Study: The Indonesian Ethnic Chinese}

Having said that a diaspora is a decentred ideational construct based on creolised or hybridised identities, which are positioned within inter-cultural fields of social expediency and political strategy, refutes perceptions of diasporas as coherent systemic flows of ethnically linked individuals who through cultural bonds apply common social and political strategies in order to 
positions themselves as favourably as possible in their community of residence. A decentred conception of diaspora links perfectly to the fluidity ascribed to the international community delineated earlier on in this paper. According to the latter individuals are no longer reigned in by predatory nation states in an anarchic international community. On the contrary, because aspects of national sovereignty are rolled back by an increasing entrenching international community it allows individuals and groups to flow in and out of nations in search of work and a better life. It is such social constellations that initiate new networks and reinforce or dismantle old ones based on multicultural business relations or transnational ethnic affiliations.

How to conceptualise this flow of people and what consequences does it have for the cohesion of the individual nation state? A promising point of departure in this connection is to focus on why individuals break up from their place of residence and how the individuals within the different networks settle down in their destination communities in stead of focusing on the networks themselves as they, according to my mind, are too elusive for rigorous analysis. Most networks are generally latent and are based on more or less cohesive narratives that mainly exist in the heads of those who have used them during previous migrations, are planning to move along them or are already moving through various contact points within a diasporic network towards which the migrant feel somehow affiliated. It is thus the intension of moving within a given diasporic network or the destination for that movement that constitute the crux of our analysis. Again it is a given social and political context in one's place of residence that activates the network a migrant chooses to move along.

As we have defined a diasporic network as being a decentred, multilevelled and fractious, generally ethnically affiliated, ideational system then we have dissolved the classical perception of a home (original point of departure) and a host (the destination) as constituting the beginning and end point in a diasporic movement, as there might be several choices of what constitute 
home and host. In order to pin down what triggers individuals to activate and thus participate in such elusive networks I will in the following, for the sake of simplicity, concentrate on the Indonesian ethnic Chinese.

As it is generally local social and political circumstances, which in this particular case also include national policies on especially citizenship and national ideologies concerning multicultural coexistence as they resonate down through the various societal levels, that motivates an individual to link up to a pertinent diaspora, let us then look at how the ethnic Chinese perceive themselves and how the community of residence perceives them. Wang Gungwu (1996) employs the concept of sojourning thus employing a historical perspective in his description of ethnic Chinese in Southeast Asia. According to him a sojourner is a temporary resident who is at his new place of residence 'for the time being', that is, for a non-specified period of time. After that he returns to his original home, perhaps to repeat the trip at a later date. Gungwu notes that this concept fades into the concept of migration but that there is a time difference between the two concepts. Sojourning has been pervasive in Asia for centuries and implies that the sojourner settled down in the host community in case conditions for doing so were favourable. It was thus not only work that constituted the main driving force behind becoming a sojourner as the term migrant seems to implies (Gungwu 1996: 1-2). On the other hand, sojourning is also different from immigration as the basic notion behind the former was the temporality of the trip. Immigration implies a oneway trip with an expressed wish of settling down in a new home country. The best known example of sojourners are those coming from the southern provinces of Mainland China, especially Hakka and Hokkien speaking people who in the latter part of the $18^{\text {th }}$ Century went to West Borneo and Bangka in today's Indonesia to work in the tin mines and plantations found there. Some of those sojourners, who originally started out on a labour contract ticket stayed on in Indonesia but most went back after their work contract expired (Heidhues 1993: 68-88). 
Present day Indonesia does not have a big ethnic Chinese community compared to, for example, Malaysia. The latter has about 27 per cent ethnic Chinese out of a total population of 22 million, whereas Indonesia only has about 2.9 per cent ethnic Chinese out of a total population of about 215 millions. Most of the Indonesian ethnic Chinese originates from Fujian and/or Guangdong provinces in southeast China and can be classified into five main language groups such as Hokkien, Teochius, Cantonese, and some Hainanese from Hainan Province. The fifth main language group, Hakka, is scattered throughout southern and southeastern China originating from the provinces of Guangdong, Fujian, Jiangxi, Sichuan, Hunan, Guangxi, Yunnan, and Hainan. Some also originates from Taiwan. They are sojourners and migrants par excellence.

Traders from these areas have traveled to and from the Southeast Asian region for several centuries before the arrival of the Europeans setting up trade links to present day Vietnam, Thailand, Myanmar, Malaysia, Singapore, Indonesia, and the Philippines. ${ }^{5}$ In relation to the ethnic Chinese during the period of Dutch East Indies many of them were brought there by Dutch traders. As they were not allowed to own land they were to a great extend confined to cities and towns which resulted in the setup of a complex trade infrastructure, as this was the only avenue available to them for obtaining a livelihood. ${ }^{6}$ The ethnic Chinese were thus mainly recruited by the Dutch to serve as middlemen between the colonial authorities and the local population. This colonial policy of non-integration and non-assimilation into the Indonesian society have had grave implications for the ethnic Chinese ever since, as they have frequently been accused by Indonesians for sitting heavily on trade and finance thus making it difficult for Indonesians to move into these areas. For this historical conditioned reason the ethnic Chinese have been made scapegoats whenever social and political crises have eventuated in Indonesia. 
When taking a closer look at the Indonesian ethnic Chinese community two main groups' stands out. The first one is the Peranakan and the other one Totok. Peranakans ${ }^{7}$ was formerly known as Ali-Baba. The latter originates from 'Ali', which means pribumi (indigenous people) and 'Baba', which means 'Indonesian born Chinese'. Ali-Baba used their local status to claim a higher status over the Sinkeh, the new Chinese immigrants (Beng 1997: 25-26). The modern usage of Ali-Baba refers to a joint Indonesian-Chinese business or more specifically to an Indonesian frontman in an enterprise secretly financed by an ethnic Chinese. According to William Skinner (1996:78-79) Peranakan refers to ethnic Chinese who had developed a creolised or mestizo culture with strong Indonesian characteristics. These Chinese are descendants from the original immigrants to Indonesia or imported by the Dutch during the early colonial period as traders and contract labours. The most important characteristics of the Peranakans were and still are that they marry local Indonesian women and speak Bahasa Indonesia within the family. Proficiency in Chinese languages and knowledge of traditional Chinese culture has gradually disappeared. Today most Peranakans do not speak, read or write Chinese.

The other main group of Indonesian ethnic Chinese is the Totok. This term refers to a full-blooded Chinese in Indonesia. They are recent immigrants or children of recent immigrants, who speak a Chinese language and practice traditional Chinese customs within the family (William Skinner 1997: 86, 8892). They were originally contract labours during the 1920 s and 1930 s where the immigration rate was at an average of 4.3 per cent annually. This immigration rate fell rather sharply after WWII and came to a complete stand still in the early 1950s, where the Indonesian authorities did not allow further Chinese immigrants. They came mainly from Hokkien, Cantonese, and Hakka language groups. The Totoks practice speech-group identification as an important means for identifying group membership. Because of laws implemented in 1959 and onwards forbidding non-Indonesian people to engage in retail trade outside towns many Totoks moved from the Outer 
Islands to centres of economic activities, especially around Jakarta and other main cities where their main markets were. Modern Indonesian Chinese business culture is mainly dominated by Totoks.

The Indonesian authorities and society in general have always been ambivalent towards the ethnic Chinese. It seems as if there exists a certain inclination towards anti-Chinese riots down through the post-colonial and colonial history. This can be seen when comparing negative social, economic, and political development and the appearance of anti-Chinese riots. A main precondition for this correlation, it seems to me, is that the Chinese is generally conceived of as a foreign minority and thus non-Pribumi. Furthermore, besides the before mentioned Indonesian grievances towards the ethnic Chinese for dominating the economy, international political developments have also helped fuelling anti-ethnic Chinese resentments.

For example, in the early 1950s the newly established communist government in China opened an embassy in Jakarta's China town which was followed-up by a number of consulates in other major cities. The diplomats were very active in contacting the ethnic Chinese. It resulted in a resinification of the Chinese community in terms of an increasing circulation of Chinese literature, the opening of many Chinese language schools, practices of Chinese religions together with building of temples throughout the country. The main aim of these activities was the reorganisation of the ethnic Chinese as an ethnic group, which were to exist on an equal footing with the other ethnic groups in Indonesia. It was a process of integration not assimilation.

This development brought the Chinese communities into the limelight and questions of political loyalty and national belonging became a hotly debated topic. According to Tan (1997), of the 2.45 million ethnic Chinese believed to live in Indonesia at that time, about one million could be considered having dual nationality; that is, having citizenship in both China and Indonesia. In order to correct this it was decided to force the ethnic 
Chinese to make a choice between citizenship in one or the other country. This resulted in the Sino-Indonesian Treaty on Dual Nationality, signed in Bandung on 22 April 1955. It stipulated that the ethnic Chinese had to choose which nationality they preferred during the period January 1960 to January 1962. Most of the about one million ethnic Chinese with dual nationality registered and of them about 65 per cent opted for Indonesian citizenship. In practice this meant a huge exodus of ethnic Chinese, about 400,000 people, from Indonesia, heading towards the new Chinese nation (Tan 1997: 33-35).

The plight of the ethnic Chinese had, however, only started. In 1957 the authorities demanded that all Indonesian citizens attended Indonesian schools. This meant that thousands of Chinese schools were closed. The period around 1965-66 was a particular bad one as many Chinese were killed and driven out of, for example, Aceh, North Sumatra, and rural areas in west Kalimantan. The main reason was that especially the political elite and the military thought the ethnic Chinese were collaborating with the Indonesian communist party $(\mathrm{PKI})$ and that the first president Sukarno were relying too much of the Chinese and PKI for political support.

This further changed dramatically when President Suharto's New Order regime (1966-1998) replaced what was left of Sukarno's Guided Democracy in 1965. The new regime initiated an intense programme of assimilating the ethnic Chinese into the Indonesian community by forbidding Chinese names, signs in Chinese characters in public places, publications, cultural and religious practices, constructions of new temples, etc. so as to domesticate and pull the Chinese into mainstream New Order Indonesia. Nonetheless, despite these assimilatory measures the ethnic Chinese were still marked out both in terms of education, that is, they could not join the majority of universities and could not get employment in the bureaucracy and military. Even the most assimilated ethnic Chinese was marked out as all Chinese had a code in their passport that indicated they were of Chinese descent and thus not 'blue-blooded' pribumi Indonesians. ${ }^{8}$ 
Things changed again after President Suharto was toppled in May 1998. The interim president Habibie and the following two presidents, Abdurrahman Wahid and Megawati Sukarnoputri, allowed the ethnic Chinese to practice their traditions, especially the Chinese New Year, learn Chinese languages, publicise newspapers and books in Chinese, and generally make Chinese culture more visible in the Indonesian society. The forced assimilation programme was thus formally abolished. This new zeitgeist was stipulated by a presidential degree issued in 1998 that instructed ministers and chiefs within the bureaucracy to scrap all discriminatory practices against the ethnic Chinese. And in May 1999 Chinese initiated political parties such as the Chinese-Indonesian Reform Party were formed and the renowned economist Kwik Kian Gie became deputy chairman of Megawati Sukarnoputri's Indonesian Democratic Party of Struggle (PDI-P). Later on the same year he became Coordinating Minister for Economy, Finance and Industry in the Abdurrahman Wahid/Megawati Sukarnoputri administration. He was thus the first ethnic Chinese to attain a ministerial portfolio in the postSuharto era. After sizing power in July 2001 Megawati Sukarnoputri's administration, represented by the Minister of Religious Affairs issued Decree No. 13 stipulating that Imlek or the Chinese New Year was a national holiday. On the basis of these changes life for the Indonesian ethnic Chinese became somewhat easier. The current president, Susilo Bambang Yudhojono, has continued the reconciliatory approach towards the Chinese.

These changes, however positive they might be, also posed new challenges for the ethnic Chinese community. The remaining discrimination against them, especially in terms of obtaining Indonesian citizenship and having to state their ethnic belonging in their passport, still lingers on not forgetting the general anti-Chinese sentiment in the Indonesian society, carefully nurtured by the New Order regime throughout the 32 years it existed. What is more problematic, however, is a growing split within the ethnic Chinese community itself, a split that revolves around the question of identity. Although not an entirely new problem the question of how to designate 
themselves has really come to the forefront in the post-Suharto era. Labels such as Overseas Chinese, Ethnic Chinese, Chinese nationals or Nationals of Chinese Descent have been applied to the Chinese, not only in Indonesia, but throughout Southeast Asia, indicating a tense relationship amongst the ethnic Chinese, their respective nation states, and Mainland China thus turning an ethnic label into an important political signifier. For example, Suryadinata (1997: 20) writes that for recent migrants their ethnic identity is stronger than their national identity. This is not a problem when China's relations with the individual Southeast Asian state are cordial. But when China-Southeast Asian relations turn sour then the ethnic Chinese generally become the focus of resentment from the indigenous people.

This international tendency of classifying the ethnic Chinese in Southeast Asia as nationalised foreigners with a doubtful political loyalty towards their communities of residence also poses tremendously problems for the ethnic Chinese themselves. If labelled Overseas Chinese then they are not thought of as true nationals in their community of residence, only sojourners with perceived strong ties to Mainland China, which might pose a political threat, and even if labelled Ethnic Chinese with many generations in their host community behind them as evidence of their adherence to their host turned national community, then they are more or less social and political marginalised as can be seen in especially Indonesia, Malaysia, and the Philippines. This dual nature of identity on behalf of the ethnic Chinese thus represents a national security liability. As Tan Chee Beng (1997) states in a response to Leo Suryadinata on the status of the ethnic Chinese in a Southeast Asian context,

Ethnic Chinese perceives themselves as nationals and not overseas Chinese. Their homeland is thus their father/mother-land, not Mainland China. Overall, the Chinese in Southeast Asia should not be called 'Overseas Chinese' as it is a label which is appropriate only for citizens of China living overseas. 
He concludes:

As proud citizens of our respective countries, we feel insulted to be called or even referred to as 'Overseas Chinese'. We are overseas in China but not when we are at home in Malaysia, Indonesia, the Philippines, and so forth (Beng 1997:25-32).

The main question here is whether the Southeast Asian states, especially Indonesia, will let the ethnic Chinese themselves decide what they prefer to be labelled. As we have seen in the case of Indonesia, at the bottom line it is national politics that decide what label to apply to the ethnic Chinese. Parallel to these external discourses internal fault-lines from within the Indonesian ethnic Chinese communities themselves are gradually surfacing. I am here referring to the distinction between Peranakans and Totoks.

Today the relationship between Peranakans and Totoks highlights the heterogeneity of the ethnic Chinese community in Southeast Asia. Anyway, they have never been a homogeneous group as also maintained by Suryadinata (1997), as the ethnic Chinese reflect different social and political circumstances in their respective host communities as well as different circumstances under which they became ethnic Chinese in a Southeast Asian context. The difference between the Peranakans and Totoks thus represent a further differentiation of the ethnic Chinese community. The first stands for assimilation into the Indonesian community. The latter are also trying to accommodate assimilation policies but with due respect towards Chinese culture and traditions and not the least towards the ancient 'homeland' China. Furthermore, current tensions between these two groups also link up to international relations even though they are played out in a local setting. For example, in the shadow of Mainland China's ascendance towards economic superpower status, Totoks tries to re-sinicise the Peranakans so as to make them remember and thus re-inculcate their ethnic and cultural background. This re-sinification process seems to gain momentum among the Indonesian 
ethnic Chinese community especially after Suharto was forced to step down in May 1998 thereby making them more visible as a distinct ethnic group that demands cultural autonomy and political recognition on an equal footing along with other ethnic groups from the Indonesian state. If history has a tendency to repeat itself then this new visibility and the more or less conflicting strategies emanating from within the Indonesian ethnic Chinese community makes it an ambivalent and multi-directional ethnic group towards which many Indonesians, and especially the political elite, have difficulty relating to in terms of questions of identity and political loyalty. As the Indonesian society is still undergoing profound societal transformations the plight of the ethnic Chinese thus seems far from over taking their violent and scapegoating historical precedence into account.

\section{The Ethnic Chinese Diaspora and Contemporary Processes of Globalisation: Some Concluding Remarks}

As can be seen the ethnic Chinese community in Indonesia is being squeezed by various national as well as international requests for social and political conformity, which include a high degree of ethnic and cultural stereotyping thus intensifying old grievances and new frictions within the ethnic Chinese communities and between them and various sections in the Indonesian society. Furthermore, as the largest enterprises in modern ethnic Chinese business culture are dominated by Totoks this puts further pressure on the relationship between the Peranakans and the Totoks in terms of economic and political positioning in their respective fields of interests. This insight becomes so much more important taking the growing economic cooperation between Mainland China and Indonesia into account. Peranakans are thus gradually becoming economically and as well as politically marginalised in relation to social status both within the ethnic Chinese community and in the Indonesian society in general due to their muted cultural affiliations. There is thus a pressure on the Peranakans to become Totoks through processes of re-sinification if they are to succeed in 
business. Additional insight into these developments is pending further research.

It is a combination of these different types of pressure on the individual ethnic Chinese that triggers his or her desire to relate to an affiliated diasporic network in order to try his or her luck in another community in case the pressure becomes too much to bear in the place of residence. Processes of social uprooting like these followed by actual moving to another host community, nationally or transnationally, can be characterised as sojourning or perhaps better as attempts to assess whether a new location provides better security and opportunities compared to the current place of residence. In case the new place of residence turns out to be a viable alternative in terms of a better social, economic, and political societal positioning then the sojourner transforms him- or herself into a settler in the new home community. In this way the diasporic network has become yet another reference point bigger for other sojourners to relate to in their search for an alternative and perhaps more profitable life.

Arguably, these diasporic movements differ markedly from general notions of labour migration, as they are not channelled through agents or other institutionalised recruitment centres, that they are not characterised by circular migration or other repetitive patterns of migration, and that they carry a high degree of long term settling down in the new home community. Contrary to migration patterns in general, the movements of the ethnic Chinese within the Chinese diaspora as described above provide substance to the notion that a diaspora constitutes a decentred, multi-levelled and fractious, generally ethnically affiliated, ideational network thereby confirming James Clifford's perception of diaspora as dwelling here assumes solidarity and connection there but that there is not necessarily a single place or a nation. On the contrary, there can be many 'here's' and 'there's' in such networks. It furthermore confirms Fred Riggs' perception of processes of diasporisation and de-diasporisation, as people move in and out of a given 
diaspora depending on their current social and political situation. The adherence to a perceived affiliated diaspora thus depends on a relative social, economic, and political context that might motivate an individual to break up from a known locality once an otherwise pervasive notion of trust in it has been undermined. The notion of diaspora as having a grand narrative based on a home and a destination is thus highly simplistic and can therefore not be supported.

As demonstrated in the first part of this paper the changing format of the nation state and its relationship to the likewise changing international community of which it is a constituent part has opened new windows of opportunities for moving around within the Southeast Asian region. Not only, of course, for ethnic Chinese but for all categories of labours and migrants, professionals as well as for spontaneous movements. This is not to say that we are only talking about voluntary movements in the form of labour migration, sojourning or immigration. As mentioned above, the situation on a given locality can change fast and dramatically as we saw it in the wake of the Asian financial crisis in 1997. This initiated major societal transformations in especially Indonesia, triggering massive unemployment thereby kicking off more or less forced movements of people in search of labour outside Indonesia, branching out throughout the Southeast Asian region.

This, however, is just one side of the coin. The other side reflects statist attempts of 'tightening-up' rules of citizenship thus further siphoning off huge numbers of people, as they no longer fit into pre-designed citizenship slots based on either ius sanguinis, ius soli or a combination of these two main principles of obtaining citizenship. Individuals who already lives on the margins of society are thus being targeted by the establishment which mercilessly classifies them as either denizens or even worse margizens, that is, people with very few or no rights. The case of Malaysia expelling thousands of Indonesian migrant labours is a case in point. The paradox in these developments is that the nation states cannot seal themselves off from 
the international community, as the dynamic there is based on political and economic globalisation on which every single nation state depends for its very existence. For example, the constant relocation of transnational capital flows, production practices, and business connections force the individual nation state to open up its borders for various types of labour migrant, sojourners, and immigrants in general, as their own industrial complexes and trade sectors depend on different types of human resources, which flow within and between nation states so as to be able to keep up with internal and external competitors.

This intricate interplay between nation states and processes of globalisation has as one of its main consequences that it roles back aspects of national sovereignty and thus gradually opens up the national hinterland for further international stimulus. These developments have resulted in the production of new societal spaces, which are being contested by non-statist actors based on transnational and thus more or less deterritorialised ethnic affiliated identities thus creating an alternative sense of belonging to the otherwise fixed statist's perception of citizenship. The main argument forwarded in this paper is that the ethnic Chinese utilises these relatively newly created spaces for setting up diasporic like networks thus providing substance for the establishment of transnational ethnoscapes or nations without states as they are labelled by some authors. As discussed, these networks do not have a life of their own but constitute latent possibilities which become activated when given social and political developments question the general security in the community of residence. These networks thus wax and vain according to social and political developments within the affiliated home communities. As such they facilitate movements of individuals within a given region that is circumscribed by a decentred and fragmented diasporic narrative thus providing them with an alternative way of pursuing the good life. It is developments like these that provide substance to processes of subnational regionalisation driven by a host of localised transnational social and 
political forces thus producing a more broad based integration of the region compared to statist initiated formal processes of regionalism.

\section{References}

Ang, len 2001, On Not Speaking Chinese. Living Between Asia and the West, London: Routledge.

Appadurai, Arjun 1991, 'Global Ethniscapes. Notes and Queries for a Transnational Anthropology', in Richard G. Fox (ed.), Recapturing Anthropology. Working in the Present, Santa Fe: School of American Research Press, pp. 191-210.

Beng, Tan Chee 1997, 'Comments on "Ethnic Chinese in Southeast Asia: Overseas Chinese, Chinese Overseas or Southeast Asians?"', in Leo Suryadinata (ed.), Ethnic Chinese as Southeast Asians, Singapore: Institute of Southeast Asian Studies, pp. 25-32.

Bolt, P. J. 2000, China and Southeast Asia's ethnic Chinese: state and diaspora in contemporary Asia, Westport: Praeger.

Brah, A. 1996, Cartographies of Diaspora. Contesting identities, London: Routledge.

Callahan, W. A. 2002, Diaspora, cosmopolitanism and nationalism: overseas Chinese and neo-nationalism in China and Thailand, Hong Kong: City University of Hong Kong, Southeast Asia Research Centre, Working Paper Series no. 35.

Castles, Stephen and Alastair Davidson 2000, Citizenship and Migration. Globalisation and the Politics of Belonging, London: Macmillan Press.

Chin Ung Ho 2000, The Chinese of Southeast Asia, London: Minority Rights Group.

Clifford, J. 1994, 'Diasporas', Cultural Anthropology, 9(3), pp. 302-338.

Cohen, R. 1997, Global Diaspora: an introduction, London: UCL Press.

Cribb, Robert (2000), 'Political Structures and Chinese Business Connections in the Malay World: A Historical Perspective', in Chan Kwok Bun (ed.), Chinese Business Networks. States, Economy and Culture. Singapore: Prentice Hall, pp. 176-92.

Dirlik, A 1996, 'Critical reflections on "Chinese Capitalism" as a paradigm', in A. Brown (ed.), Chinese business enterprise, Vol. I, London: Routledge, pp. 17-38. 
Friedman, Jonathan 1998, 'Indigenes, Cosmopolitans and the Discreet Charm of the Bourgeoisie', in: Udvalgte oplæg fra årsmøde i 1998. Dansk Ethnografisk Forening, Grænser for Globalisering, Aahus and Copenhagen: University of Aahus, pp. 1-20.

Gomez, E. T. 2004, 'De-Essentialising Capitalism: Chinese Networks and Family Firms in Malaysia', in NIAS Nytt: Asia Insights. No. 3. Sep., pp. 8-10. Gomez, E. T. and H. M. Hsiao 2001, Chinese business in Southeast Asia: contesting cultural explanations, researching entrepreneurship, Richmond: Curzon Press.

Guibernau, Maria Montserrat 1996, Nationalisms: the nation-state and nationalism in the twentieth century, Cambridge: Polity Press.

Gungwu, Wang 1996, 'Sojourning: The Chinese Experience in Southeast Asia', in Anthony Reid (ed.), Sojourners and Settlers. Histories of Southeast Asia and the Chinese, North Sydney: Allen \& Unwin, pp. 1-14.

Harvey, David 1989, The Condition of Postmodernity. An Enquiry into the Origins of Cultural Change, Cambridge: Basil Blackwell.

Heidhues, Mary Somers 1993, 'Chinese Organisations in West Borneo and Bangka: Kongsi and Hui', in David Ownby and Mary Somers Heidhues (eds), 'Secret Societies' Reconsidered. Perspectives on the Social History of Modern South China and Southeast Asia, New York: M.E. Sharpe Inc., pp. 68-88.

----- 1996, 'Chinese Settlements in Rural Southeast Asia: Unwritten Hinstories', in Anthony Reid (ed.), Sojourners and Settlers. Histories of Southeast Asia and the Chinese, North Sydney: Allen \& Unwin, pp. 164-82.

Holm, Hans-Henrik and Georg Sørensen 1995, Whose World Order? Uneven Globalisation and the End of the Cold War, Boulder: Westview Press.

Jackson, Robert K. 1990, Quasi-States: Sovereignty, International Relations, and the Third World, Cambridge: Cambridge University Press.

Jacobson, David. 1998, 'New Border Customs: Migration and the Changing Role of the State'. Journal of International Law and Foreign Affairs, 3, 2, pp. 443-62.

Jacobsen, Michael 2002, 'Appropriating the Global within the Local: Identity Formation Among the Minahasa in Contemporary Indonesia', in Catarina Kinnvall and Kristina Jönsson (eds.), 'Globalisation and Democratisation in Asia: The Construction of Identity, London: Routledge, pp. 230-46.

2004, 'Factionalism and Secessionism in North Sulawesi Province, Indonesia', Asia Journal of Political Science. Vol. 12. No. 1 June, pp. 65-94. 
2005, 'Islam and Processes of Minorisation among Ethnic Chinese in Indonesia: Oscillating between Faith and Political Economic Expediency'. Asia Ethnicity. Vol. 6. No. 2. June, pp. 71-88.

2007, 'Doing Business the Chinese Way? On Manadonese Chinese Entrepreneurship in North Sulawesi'. To be published in Copenhagen Journal of Asian Studies medio 2007.

Kotkin, J. 1992, Tribes: how race, religion, and identity determine success in the New Global Economy, New York: Random House.

Krasner, Stephen D. 1999, Sovereignty: Organised Hypocrisy, Princeton: Princeton University Press.

Li, J. and P. C. Wright 1999, The issue of Guanxi: discrepancies, reality and implications, Hong Kong: Hong Kong Baptist University, School of Business, Business Research Centre.

Luo, Y. 2000, Guanxi and business, Singapore: World Scientific.

McKeown, A. 2001, Chinese migrant networks and cultural change: Peru, Chicago, Hawaii, 1900-1936, Chicago: The University of Chicago Press.

Omae, Ken'ichi 1995, The end of the nation state: the rise of regional economies, New York: Free Press.

Ong, Aihwa 1999, Flexible Citizenship: the Cultural Logics of Transnationality, Durham: Duke University Press.

Pann, Lyn (ed.) 1999, The Encyclopedia of the Chinese Overseas, Surrey: Curzon Press.

Reid, Anthony (ed.) 1993, Southeast Asia in the Early Modern Era: Trade, Power, and Belief, Ithaca: Cornell University Press.

Riggs, F. W. 2001, Glocalization, Diaspora and Area Studies, pp. 1-4. http://www2.hawaii.edu/ fredr/glocal.htm

Safran, W. 1999, 'Comparing diasporas: a review essay', Diaspora, 8, 3, pp. 255-91.

Sassen, S. 2000, 'Spatialities and Temporalities of the Global: Elements for a Theorization', Public Culture, 12, 1, pp. 215-32.

Sautman, Barry 2002, Hong Kong as a Semi-Ethnocracy: 'Race', Migration, and ${ }^{9}$ Citizenship in a Globalised Region, Division of Social Science, Hong Kong University of Science and Technology. Mimeographed Draft of 29 October. 
Shuval, J. 2000, 'Diaspora migrations: definitional ambiguities and a theoretical paradigm', International Migration, 38, 5, pp. 41-55.

Skinner, G. William 1996, 'Creolized Chinese Societies in Southeast Asia', in Anthony Reid (ed.), Sojourners and Settlers. Histories of Southeast Asia and the Chinese, North Sydney: Allen \& Unwin, pp. 51-93.

Suryadinata, Leo 1997, 'Ethnic Chinese in Southeast Asia: Overseas Chinese, Chinese Overseas or Southeast Asians?', in Leo Suryadinata (ed.), Ethnic Chinese as Southeast Asians, Singapore: Institute of Southeast Asian Studies, pp. 1-24.

Tan, Mely G. 1997, 'The Ethnic Chinese in Indonesia: Issues of Identity', in Leo Suryadinata (ed.), Ethnic Chinese as Southeast Asians. Singapore: Institute of Southeast Asian Studies, pp. 33-65.

Weidenbaum, M. \& S. Hughes 1996, The bamboo network. How expatriate Chinese entrepreneurs are creating a new economic superpower in Asia, London: The Free Press.

Wong, J. 1998, Southeast Asian Ethnic Chinese Investing in China, East Asian Institute, Singagpore: National University of Singapore, Working Paper No. 15.

Yang, M. M. 1994, Gifts, favours, and banquets: the art of social relationships in China, Ithaca: Cornell University Press.

Yao, Souchou (2002), 'Guanxi: Sentiment, Performance and the Trading of Words', in Thomas Menkhoff and Solvay Gerke (eds), Chinese Entrepreneurship and Asian Business Networks. London and New York: Routledge/Curzon, pp. 233-54.

\footnotetext{
${ }^{1}$ See also Friedman (1998: 1-19), Brown (1995: 54-68), Smith (1990: 171-91).

${ }^{2}$ For a general discussion of the relationship between minority rights, national sovereignty, and the international human rights regime, see Castles and Davidson (2000: 208-12).

${ }^{3}$ See also Li and Wright 1999.

${ }^{4}$ I have discussed the fluidity and thus political expediency of ethnic identity extensively in Jacobsen (2004).

${ }^{5}$ For a general overview see Reid (1996), Jacobsen (2005) and Suryadinata (1997).

${ }^{6}$ For details on Chinese settlements in rural Southeast Asia see Heidhues (1996: 164-82).

${ }^{7}$ This word derives linguistically from the Malay word anak, which means 'child'.

${ }^{8}$ For further details, see Pan 1999: 157-60.
} 


\section{COPENHAGEN DISCUSSION PAPERS}

2005:

2005-1 May: Can-Seng Ooi, "Orientalists Imaginations and Touristification af Museums: Experiences from Singapore".

2005-2 June: Verner Worm, Xiaojun Xu, and Jai B. P. Sinha, "Moderating Effects of Culture in Transfer of Konwledge: A Case of Danish Multinationals and their Subsidiaries in P. R. China and India".

2005-3 June: Peter Wad, "Global Challenges and Local Responses: Trade Unions in the Korean and Malaysian Auto Industries".

2005-4 November: Lenore Lyons, "Making Citizen Babies for Papa: Feminist Responses to Reproductive Policy in Singapore".

2006:

2006-5 April: Juliette Koning," On Being "Chinese Overseas": the Case of Chinese Indonesian Entrepreneurs".

2006-6 April: Mads Holst Jensen, "Serve the People! Corporate Social Responsibility (CSR) in China".

2006-7 April: Edmund Terence Gomez, "Malaysian Investments in China: Transnationalism and the 'Chineseness' of Enterprise Development".

2006-8 April: Kate Hannan, "China's Trade Relations with the US and the EU WTO Membership, Free Markets (?), Agricultural Subsidies and Clothing, Textile and Footwear Quotas".

2006-9 May: Can- Seng Ooi, "Tales From Two Countries: The Place Brandin g of Denmark and Singapore".

2006-10 May: Gordon C. K. Cheung, "Identity: In Searching the Meaning of Chineseness in Greater China

2006-11 May: Heidi Dahles, 'CHINESENESS' AS A COMPETITIVE DISADVANTAGE, Singapore Chinese business strategies after failing in China

2006-12 June: Émile Kok- Kheng Yeoh, Development Policy, Demographic Diversity and Interregional Disparities in China 
2006-13 June: Johannes Dragsbaek Schmidt, China's "soft power" reemergence in Southeast Asia

2006-14 September: Michael Jacobsen, Beyond Chinese Capitalism: ReConceptualising Notions of Chinese-ness in a Southeast Asian Business cum Societal Context

2006-15 October: Ng Beoy Kui, The Economic Rise of China: Its Threats and Opportunities from the Perspective of Southeast Asia 